\title{
KEDUDUKAN KOMISI PEMBERANTASAN KORUPSI DALAM SISTEM KETATANEGARAAN INDONESIA
}

\author{
Mahesa Rannie \\ Dosen, Fakultas Hukum Universitas Sriwijaya \\ mahesarannie@fh.unsri.ac.id
}

\begin{abstract}
Abstrak
Kedudukan Komisi Pemberantasan Korupsi (KPK) dalam sistem ketatanegaraan Indonesia memang seringkali diperdebatkan, hal ini terbukti dengan Putusan-Putusan MK yang berubah-ubah.Mahkamah Konstitusi dalam putusannya pernah beberapa kali memutuskan berbeda tentang kedudukan KPK ini dalam sistem ketatanegaraan Indonesia.Mahkamah Konstitusi pernah memutuskan KPK merupakan lembaga negara independen di luar ranah kekuasaan eksekutif, legislatif, dan yudikatif.Pernah pula memutuskan bahwa KPK merupakan eksekutif dilihat dari kewenangannya.Putusan-putusan MK ini tentu saja membawa pengaruh terhadap undang-undang KPK. Revisi undang-undang KPK terbaru, yaitu Undang-Undang Nomor 19 Tahun 2019 menyatakan KPK masuk dalam ranah kekuasaan eksekutif sehingga dengan demikian KPK dapat menjadi objek hak angket Dewan Perwakilan Rakyat (DPR). Hal demikian tentu saja menambah panjang perdebatan di kalangan ahli hukum dengan argumentasinya masing-masing.Dari argumenttasi-argumentasi tersebut penulis menganggap KPK adalah lembaga negara independen di luar struktur organ negara yang utama.Hal ini sejalan dengan theory the new separation of power sebagai konsekuensi dari teori negara kesejahteraan (welfare state) di era abad modern ini. Sebagai lembaga negara independen yang kedudukannya tidak sekuat lembaga negara utama dalam ranah kekuasaan eksekutif, legislatif, dan yudikatif tentu saja KPK bisa dibubarkan jika lembaga yang selama ini sebetulnya mempunyai wewenang kuat untuk melaksanakan penegakan hukum dalam rangka pemberantasan tindak pidana korupsi (Kepolisian dan Kejaksaan) mampu berbenah diri. Selama belum mampu berbenah maka wewenang tersebut bisa dilaksanakan oleh KPK yang keberadaannya sampai saat ini masih tetap diperlukan dalam rangka pemberantasan tindak pidana korupsi di Indonesia.
\end{abstract}

\section{Kata kunci: Kedudukan KPK, Sistem Ketatanegaraan, Indonesia}

\begin{abstract}
The position of the Corruption Eradication Commission (KPK) in the constitutional system of Indonesia is often debated. This is evidenced by the inconsistent decisions of the Constitutional Court. The Constitutional Court has ever madedifferent decisions several times regarding the position of the Corruption Eradication Commission (KPK) in the constitutional system of Indonesia.The Constitutional Court once decided that the Corruption Eradication Commission (KPK) was an independent state institution outside the realm of executive, legislative and judicial powers. It has also decided that the Corruption Eradication Commission (KPK) is an executive body in terms of its authority. These inconsistent decisions of the Constitutional Court, of course, have an influence on the law of the Corruption Eradication Commission (KPK). The latest revision of the law of the Corruption Eradication Commission (KPK), namely the Law Number 19 of 2019 states that the Corruption Eradication Commission (KPK) is classified to be in the realm of executive power so that the Corruption Eradication Commission (KPK) can become the object of the
\end{abstract}


right to inquiry by the House of Representatives (DPR).This situation, of course, adds to the length of debate among legal experts with their respective arguments. Based on these arguments, the writer considers that the Corruption Eradication Commission (KPK) is an independent state institution outside the main state organ structure. This is in line with the theory of the new separation of power as a consequence of the theory of the welfare state in this modern era. As an independent state institution whose position is not as strong as the main state institutions in the realm of executive, legislative and judicial powers, of course, the Corruption Eradication Commission (KPK) can be dissolved if the institutions that actually have strong authority to carry out law enforcement in the context of eradicating criminal acts of corruption (Police and Prosecutors) are able to empower themselves to execute their authority. However, if those institutions have not been able to execute their authority, this authority can be exercised by the Corruption Eradication Commission $(K P K)$, whose existence is still needed in the context of eradicating criminal acts of corruption in Indonesia.

\section{Keywords: Position of the Corruption Eradication Commission, Constitutional}

\section{A. Pendahuluan}

Seiring dengan bergulirnya reformasi pada tahun 1998 setelah Presiden Soeharto meletakkan jabatannya sebagai Presiden Republik Indonesia pada 21 Mei 1998, struktur ketatanegaraan Inodonesia mengalami perubahan yang sangat mendasar. Semua itu bermula dari perubahan Undang-Undang Dasar Negara Republik Indonesia (UUD NRI) 1945.Salah satu yang mengalami perubahan tersebut adalah komposisi lembaga negara ${ }^{2}$ yang ada di Indonesia.

\footnotetext{
${ }^{2}$ Sekalipun UUD NRI 1945 menggunakan istilah lembaga negara, terminologi lain selain lembaga negara seperti badan negara atau organ negara masih lazim dipakai untuk menyebut lembaga atau organ negara yang menjalankan fungsi kekuasaan negara. Dengan menggunakan istilah tersebut, yang dituju adalah sebuah institusi yang melaksanakan fungsi-fungsi negara, baik fungsi membentuk undang-undang, fungsi menjalankan undang-undang, maupun fungsi pengawasan terhadap pelaksanaan kekuasaan negaraan. Dengan demikian sebetulnya isilah lembaga negara, organ negara, atau badan negara adalah sama. Tidak berbeda jauh dengan Jimly Asshidiqie yang menyatakan bahwa lembaga negara terkadang disebut dengan istilah lembaga pemerintahan, lembaga pemerintahan nondepartemen, atau lembaga negara saja. Lembaga negara tersebut ada yang dibentuk berdasarkan Undang-Undang Dasar (UUD),
}

Sebelum perubahan UUD NRI 1945, lembaga negara di Indonesia dikategorikan menjadi lembaga tertinggi negara dan lembaga tinggi negara. Lembaga tertinggi negara adalah Majelis Permusyawaratan Rakyat (MPR) dan lembaga tinggi negara terdiri dari Dewan Perwakilan Rakyat (DPR), Mahkamah Agung (MA), Dewan Perwakilan Rakyat (DPR), Dewan Pertimbangan Agung (DPA), dan Badan Pemeriksa Keuangan (BPK). Namun setelah perubahan UUD NRI 1945, tidak ada lagi kategori lembaga tertinggi negara. Semua lembaga negara sejajar seiring dengan kesadaran akan pemahaman harus adanya prinsip saling mengawasi dan mengimbangi (checks and balances) antar lembaga negara. Setelah perubahan UUD NRI 1945 ada perubahan dalam kelembagaan negara Indonesia, di ranah kekuasaan legislative muncul Dewan Perwakilan Daerah (DPD) yg merupakan perwakilan dari provinsi-provinsi yang ada

ada pula yang dibentuk dan mendapatkan mandat dari Undang-Undang (UU), dan bahkan ada pula yang dibentuk berdasarkan Keputusan Presiden (Keppres). Hierarki kedudukannya tentu saja tergantung pada derajat pengaturannya menurut peraturan perundang-undangan yang berlaku. Saldi Isra. Lembaga Negara: Konsep Sejarah Wewenang dan Dinamika Konstitusional. Depok: PT RajaGrafindo Persada. 2020. hlm. 9. 
di seluruh Indonesia dan di ranah kekuasaan yudikatif lahir lembaga tempat pengujian undang-undang yaitu Mahkamah Konstitusi. Selain itu setelah perubahan UUD NRI 1945, banyak pula bermunculan lembaga negara baru yang sering diistilahkan dengan lembaga non struktural. ${ }^{3}$ Lembaga non struktural hanya beberapa saja yang keberadaannya disinggung implisit dan eksplisit dalam perubahan UUD NRI 1945, diantaranya adalah Komisi Yudisial (KY) dan Komisi Pemilihan Umum (KPU). Bahwa kemudian ada banyak lembaga non struktural yang terbentuk di Indonesia berdasarkan undang-undang atau peraturan lain di bawah undang-undang, salah satunya adalah Komisi Pemberantasan Korupsi (KPK). Komisi ini dibentuk sesuai dengan amanat reformasi yang digaungkan di tahun 1998 yang menginginkan penyelenggaraan negara bebas dari praktek korupsi, kolusi dan nepotisme, karena sebelum bergulirnya reformasi nyaris tidak ada kasus korupsi besar yang terungkap di permukaan, belum lagi dengan persoalan kolusi dan kongkalikong yang juga merajalela. Dalam hal ini, kehadiran KPK jelas dipandang sebagai langkah darurat untuk untuk menyelesaikan kejahatan korupsi yang luar biasa ini. Menurut Mahfud MD hal ini didasarkan pada dalil yang berbunyi "salus populi supreme lex", yang berarti keselamatan rakyat (bangsa dan negara) adalah hukum yang tertinggi. ${ }^{4}$ Artinya jika keselamatan rakyat, bangsa, dan negara sudah terancam karena keadaan yang luar biasa, maka dapat

\footnotetext{
${ }^{3}$ Merujuk pada batasan yang ditentukan oleh Lembaga Administrasi Negara, lembaga non struktural adalah institusi yang dibentuk karena urgensi terhadap tugas khusus tertentu yangtidak dapat diwadahi dalam kelembagaan pemerintah (konvensional) dengan keunikan tertentu dan memiliki karakteristik tugas yang urgen, unik, dan terintegrasi secara efektif. Hamdan Zolva. dkk. Bunga Rampai Pemikiran Penataan Lembaga Non Struktural. Jakarta: Deputi Menteri Sekretaris Negara Bidang Hubungan dan Kelembagaan. 2010. hlm. 30.

${ }^{4}$ Moh. Mahfud MD. Perdebatan Hukum Tata Negara Pasca Amandemen Konstitusi. Jakarta: PT RajaGrafindo Persada. Jakarta. 2013. hlm. 197.
}

ditempuh langkah yang bersifat darurat atau khusus untuk keluar dari keadaan darurat tersebut.

Pendirian KPK pada awalnya meniru Komisi Independen Anti Korupsi (ICAC) di Hongkong. Karakter utama lembaga tersebut adalah independensi. Dengan menjadi lembaga yang independen, KPK diharapkan akan menjadi seperti ICAC, yang mampu menangani berbagai kasus korupsi besar yang terjadi di semua lembaga negara. ${ }^{5}$ Komisi Pemberantasan Korupsi dibentuk berdasarkan Undang-Undang Nomor 30 Tahun 2002 pada masa pemerintahan Presiden Megawati Soekarnoputri. Urgensi terbentuknya KPK pada saat itu karena Presiden Megawati Soekarnoputri menilai lembaga Kejaksaan tidak mampu menangkap koruptor.Dalam menjalankan tugasnya KPK diamanatkan untuk melaksanakan pemberantasan korupsi secara profesional, intensif, dan berkesinambungan. Komisi Pemberantasan Korupsi dibentuk bukan untuk mengambil alih tugas pemberantasan korupsi dari lembaga-lembaga yang telah ada sebelumnya. Dalam penjelasan Undang-Undang Nomor 30 Tahun 2002 tentang Komisi Pemberantasan Tindak Pidana Korupsi, disebutkan bahwa KPK memiliki peran sebagai trigger mechanism, yang berarti mendorong atau sebagai stimulus agar upaya pemberantasan korupsi oleh lembaga-lembaga yang telah ada sebelumnya menjadi efektif dan efisien. ${ }^{6}$

Komisi Pemberantasan Korupsi merupakan lembaga negara yang bersifat independen dalam melaksanakan tugas dan wewenangnya serta bebas dari kekuasaan manapun sebagaimana yang tercantum dalam Pasal 3 Undang-Undang Nomor 30 Tahun 2002 tentang Komisi Pemberantasan Tindak Pidana Korupsi. ${ }^{7}$ Terkait dengan kedudukan KPK sebagai lembaga negara independen,

${ }^{5}$ Di Bawah Kendali Politik Kekuasaan. https://koran.tempo.co/read/editorial/459402/di-baw ah-kendali-politik-kekuasaan diunduh 14 Februari 2020 .

${ }^{6}$ Sekilas Komisi Pemberantasan Korupsi. https://www.kpk.go.id/id/tentang-kpk/sekilas-komisi -pemberantasan-korupsi diunduh 12 Februari 2021.

${ }^{7}$ Ibid. 
Mahkamah Konstitusi (MK) pada tahun 2017 mengeluarkan putusan yang berbeda dengan putusan-putusan yang telah ada sebelumnya. Melalui Putusan MK Nomor 36/PUU-XV/2017, Putusan MK Nomor 37, dan Putusan MK Nomor 40/PUU-XV/2017 dinyatakan bahwa MK merupakan bagian dari kekuasaan eksekutif, padahal dalam putusan-putusan MK terdahulu ${ }^{8}$ intinya menegaskan bahwa KPK adalah lembaga independen yang bukan berada dalam ranah kekuasaan trias politica (eksekutif, legislatif, dan yudikatif). Ini menjadi permasalahan yang sangat menarik dan menjadi perdebatan. Putusan MK tahun 2017 dijadikan dasar bagi Pemerintah dan DPR menjadikan KPK sebagai bagian dari kekuasaan eksekutif, melalui revisi UndangUndang KPK, yaitu Undang-Undang Nomor 19 Tahun 2019 tentang Perubahan Kedua Atas Undang-Undang Nomor 30 Tahun 2002 tentang Komisi Pemberantasan Tindak Pidana Korupsi).

\section{B. Permasalahan}

Sebenarnya kedudukan KPK sebagai lembaga negara termasuk dalam ranah kekuasaan apa dalam sistem ketatanegaraan?. Hal tersebut terus menjadi perdebatan di kalangan ahli Hukum Tata Negara dan akan dianalisis serta diulas oleh penulis dalam tulisan ini.

\section{Pembahasan}

Prinsip negara kesejahteraan (welfare state) berkembang di Eropa akhir abab ke 19 sebagai bentuk reaksi terhadap kelemahan paham liberalisme dan kapitalisme ${ }^{9}$

8 Putusan-putusan MK terdahulu yang dimaksud sebelum keluarnya Putusan MK Nomor 36/PUU-XV/2017, Putusan MK Nomor 37/PUU-XV/2017, dan Putusan MK Nomor 40/PUU-XV/2017, antara lain adalah Putusan MK Nomor 012-016-019/PUU-IV/2006, Putusan MK Nomor 19/PUU-V/2007, Putusan MK Nomor 37-39/PUU-VIII/2010, dan Putusan Mahkamah Konstitusi Nomor 5/PUU-IX/2011.

${ }^{9}$ Liberalisme adalah sebuah ideologi atau paham politik dan ekonomi yang menghendaki demokrasi dan kebebasan individu untuk berusaha dan berniaga.Dalam hal ini pemerintah/negara tidak boleh ikut campur.Sementara itu kapitalisme adalah klasik dan sekaligus reaksi terhadap konsep "negara penjaga malam" (nachtwwachtersstaat) yang mengidealkan prinsip "pemerintah yang paling baik adalah yang memerintah sesedikit mungkin" (the best governnment is the least government). ${ }^{10}$ Prinsip negara kesejahteraan juga merupakan reaksi terhadap ideologi atau paham sosialisme $^{11}$ yang kemudian berkembang menjadi totalitarian collectivism, yang berarti mengancam kemerdekaan individu. ${ }^{12}$ Kendati sebenarnya paham sosialisme ini sudah ditinggalkan (terutama di banyak negara), bukan berarti ide-idenya tidak dipraktekkan secara sengaja atau tidak sengaja. Hal ini kemudian menjadi pendorong munculnya prinsip negara kesejahteraan, yaitu sebuah konsep pemerintahan dimana negara memegang peranan penting dalam memajukan dan melindungi kesejahteraan ekonomi maupun kehidupan sosial rakyatnya.

Era negara kesejahteraan ini ditandai dengan adanya kebutuhan dan intervensi negara di segala bidang kehidupan masyarakat, untuk menghadapi perkembangan serta kompleksitas dalam praktek ketatanegaraan di abad modern. ${ }^{13}$ Sebagai konsekuensi

sebuah paham dalam sistem ekonomi yang bertujuan memperoleh keuntungan semata atas perdagangan, industri, dan alat-alat produksi dalam kegiatan ekonomi pasar.

${ }^{10}$ I D.G. Palguna.Welfare State vs Globalisasi: Gagasan Negara Kesejahteraan di Indonesia, PT RajaGrafindo Persada. Depok. 2019. hlm. 20

${ }^{11}$ Sosialisme adalah ideologi atau paham politik atau ekonomi yang berusaha supaya harta benda, industri, alat produksi dimiliki secara kolektif oleh negara.

\footnotetext{
${ }^{12}$ Ibid. hlm. 21

13 Ismail Aris. Kedudukan KPK Dalam
} Sistem Ketatanegaraan Dalam Perspektif Teori The New Separation of Power (Kritik Atas Putusan Mahkamah Konstitusi No, 36/PUU-XV/2017 dan No. 40/PUU-XV/2017. Jurnal Jurisprudentie. Fakultas Syariah dan Hukum Universitas Islam Negeri Alauddin Makassar.Volume 5 Nomor 1 Juni 2018.hlm. 101. 
gagasan negara kesejahteraan tersebut, maka munculnya kehadiran lembaga negara baru di luar prinsip trias politica untuk melayani kebutuhan dan kepentingan masyarakat yang belum tertangani di era-era sebelumnya adalah sebuah keharusan. Logika ketatanegaraan yang demikian, sesuai dan berhubungan eratdengan kelahiran serta bermunculnya lembaga negara yang tidak pernah dikenal sebelumnya.

Prinsip trias politica awal mulanya dikemukakan oleh John Locke dari Inggris yang terdiri dari eksekutif (menjalankan undang-undang), legislatif (membuat undang-undang), dan federatif (mengurusi urusan luar negeri) lalu kemudian disempurnakan oleh Montesquieu pada masa Revolusi Perancis dengan memasukkan unsur federatif menjadi bagian dari eksekutif, dan memisahkan yudikatif menjadi fungsi tersendiri yang sebelumnya adalah bagian dari eksekutif. Montesquieu sengaja memisahkan yudikatif menjadi fungsi tersendiri lepas dari eksekutif karena pengalamannya sebagai seorang hakim.Montesquieu berpendapat bahwa seorang hakim dalam menjalankan tugas harus independen dan bebas dari intervensi kekuasaan apapun, termasuk eksekutif. Dari teori trias politica tersebut berkembanglah menjadi teori pemisahan dan pembagian kekuasaan (separation/distribution of power) yang diimbangi dengan checks and balances antar lembaga negara.

Dalam perkembangan negara selanjutnya, keberadaan lembaga negara utama yang terangkum dalam "trias politica" tidaklah cukup. Menurut I Gde Panca Astawa (Mantan Hakim Konstitusi Republik Indonesia), hal-hal yang melatarbelakangi munculnya state auxiliary organs atau lembaga negara penunjang (terutama) di Indonesia adalah : ${ }^{14}$

1. Adanya kebutuhan akan dekonsentrasi kekuasaan dari tangan birokrasi ataupun

14 Rahadian Salman, Hadi Subhan, dkk. Bunga Rampai Pemikiran Penataan Lembaga Non Struktural.Op. Cit. hlm. 136-137. organ-organ konvensional pemerintahan yang dinilai birokratis, sentralistik, lamban, serta memiliki kinerja buruk;

2. Sebagai akibat dari ketidakpercayaan atas lembaga-lembaga negara yang telah ada sebelumnya;

3. Dinamika atau perkembangan masyarakat baik secara ekonomi, politik, maupun sosial budaya serta adanya pengaruh global, menghendaki struktur organisasi negara lebih responsif terhadap tuntutan yang mucul dan berkembang di tengah-tengah masyarakat luas;

4. Sebagai akibat tuntutan perkembangan masyarakat yang semakin kompleks dan rumit dan organisasi-organisasi kekuasaan yang bersifat birokratis, sentralistik, lamban, dan berkinerja buruk tidak dapat diandalkan lagi.

Dilatarbelakangi oleh penegakan hukum untuk memberantas tindak pidana korupsi yang dilakukan secara konvensional selama ini di Indonesia terbukti mengalami berbagai hambatan. Oleh karena persoalan korupsi di Indonesia sudah akut, maka diperlukan metode penegakan hukum secara luar biasa melalui pembentukan suatu badan khusus yang mempunyai kewenangan luas, independen, serta bebas dari kekuasaan manapun dalam upaya pemberantasan tindak pidana korupsi. ${ }^{15}$ Begitu parahnya maka korupsi di Indonesia dapat dikategorikan sebagai tindak pidana luar biasa (extra ordinary crime). Untuk itulah cara penanganan korupsi di Indonesia harus dilakukan dengan luar biasa. Atas dasar itulah dibentuk KPK yang mempunyai wewenang luar biasa, sehingga sebagian kalangan hukum menyebutnya sebagai suatu lembaga super (super body). ${ }^{16}$ Dalam menjalankan kewena-

${ }^{15}$ Mudzakkir, dkk.Laporan Akhir Tim Kompendium Hukum Badan Pembinaan Hukum Nasional Kementerian Hukum dan Hak Asasi Manusia Republik Indonesia Tentang Lembaga Pemberantasan Korupsi Tahun 2011.https://bphn.go.id/data/documents/kpd-2011-7. pdfdiunduh 16 Februari 2021.

${ }^{16}$ Ibid. 
ngannya tersebut KPK menurut Pasal 6 butir $\mathrm{b}, \mathrm{c}, \mathrm{d}$, dan e Undang-Undang Nomor 30 Tahun 2002 tentang Komisi Pemberantasan Tindak Pidana Korupsi dapat bertindak mulai dari $:^{17}$

1. Mensupervisi terhadap instansi yang berwenang melakukan tindak pidana korupsi;

2. Melakukan penyelidikan, penyidikan, dan penuntutan terhadap tindak pidana korupsi;

3. Melakukan tindakan pencegahan korupsi;

4. Memonitor terhadap penyelenggaraan pemerintahan negara.

Selain itu KPK dapat pula mengambil alih kasus korupsi yang sedang ditangani kepolisian atau kejaksaan apabila $:^{18}$

1. Laporan masyarakat mengenai tindak pidana korupsi tidak ditindaklanjuti;

2. Proses penanganan tindak pidana korupsi tidak ada kemajuan, berlarut-larut, atau

tertunda tanpa alasan jelas yang dapat dipertangungjawabkan;

3. Penanganan tindak pidana korupsi ditujukan untuk melindungi pelaku korupsi yang sesungguhnya;

\footnotetext{
${ }^{17}$ Dalam Undang-Undang Nomor 19 Tahun 2019 tentang Perubahan Kedua Atas Undang-Undang Nomor 30 Tahun 2002 tentang Komisi Pemberantasan Tindak Pidana Korupsi Pasal 6 butir b, c, d, dan e mengalami perubahan, sehingga bunyinya menjadi : Komisi Pemberantasan Korupsi bertugas melakukan :

b. koordinasi dengan instansi yang berwenang melaksanakan pemberantasan tindak pidana korupsi dan

instansi yang bertugas melaksanakan pelayanan publik;

c. monitor terhadap penyelenggaraan pemerintahan negara;

d. supervisi terhadap instansi yang berwenang melaksanakan pemberantasan tindak pidana korupsi; e. penyelidikan, penyidikan, dan penuntutan terhadap tindak pidana korupsi.

${ }^{18}$ Dalam Undang-Undang Nomor 19 Tahun 2019 tentang Perubahan Kedua Atas Undang-Undang Nomor 30 Tahun 2002 tentang Komisi Pemberantasan Tindak Pidana Korupsi, ketentuan ini terdapat dalam pasal baru, yaitu Pasal $10 \mathrm{~A}$ ayat 2 .
}

4. Penanganan tindak pidana korupsi mengandung unsur korupsi;

5. Adanya hambatan penanganan tindak pidana korupsi karena campur tangan dari eksekutif, legislatif, atau yudikatif;

6. Keadaan lain menurut pertimbangan kepolisian atau kejaksaan, penanganan tindak pidana korupsi sulit dilaksanakan secara baik dan dapat dipertangungjawab- kan.

Menurut Pasal 11 Undang-Undang Nomor 30 Tahun 2002, KPK juga diberi kewenangan untuk melakukan penyelidikan, penyidikan, dan penuntutan terhadap tindak pidana korupsi yang : ${ }^{19}$

1. Melibatkan aparat penegak hukum, penyelenggara negara dan orang lain yang ada kaitannya dengan tindak pidana korupsi yang dilakukan oleh aparat penegak

hukum dan penyelenggara negara;

2. Mendapat perhatian dan meresahkan masyarakat; dan/atau

3. Menyangkut kerugian negara paling sedikit Rp 1.000.000.000 (satu milyar rupiah).

Dari uraian di atas dapat dikatakan bahwa kekuasaan KPK memang didesain sedemikian rupa besarnya. Dengan begitu diharapkan akan membawa perubahan besar pula dalam upaya penegakan kasus korupsi di Indonesia. Harapan besar penegakan kasus korupsi di Indonesia setelah adanya Undang-Undang Nomor 30 Tahun 2002 memang bertumpu pada KPK.

Akan tetapi setelah munculnya revisi Undang-Undang Nomor 30 Tahun 2002 tentang Komisi Pemberantasan Tindak Pidana Korupsi menjadi Undang-Undang

${ }^{19}$ Pasal 11 ayat 1 Undang-Undang Nomor 19 Tahun 2019 tentang Perubahan Kedua Atas Undang-Undang Nomor 30 Tahun 2002 tentang Komisi Pemberantasan Tindak Pidana Korupsi berbunyi :

a. Melibatkan aparat penegak hukum, penyelenggara negara, dan orang lain yang ada kaitannya

dengan tindak pidana korupsi yang dilakukan oleh aparat penegak hukum atau penyelenggara negara; dan/atau

b. Menyangkut kerugian negara paling sedikit Rp 1.000.000.000,00 (satu milyar rupiah). 
Nomor 19 Tahun 2019 tentang Perubahan Kedua Atas Undang-Undang Nomor 30 Tahun 2002 tentang Komisi Pemberantasan Tindak Pidana Korupsi, banyak kalangan yang menilai jika kekuasaan KPK mengalami degradasi. Hal tersebut ditandai dengan munculnya Dewan Pengawas yang ada dalam tubuh KPK.Dewan Pengawan tersebut dipilih oleh Presiden. Dengan demikian artinya Presiden sebagai eksekutif mempunyai hak prerogatif untuk menentukan keanggotaan Dewan Pengawas KPK secara aklamasi maupun melalui seleksi secara terbuka. Adanya Dewan Pengawas KPK ini memang kurang tepat karena sejumlah alasan berikut ini : ${ }^{20}$

1. Dewan Pengawas KPK menjadi satu kesatuan organisasi dengan KPK, melekat bersama dengan pimpinan KPK dan pegawai KPK (Pasal 21 Ayat 1 Undang-Undang Nomor 19 Tahun 2019 tentang Perubahan Kedua Atas Undang-UndangNomor 30 Tahun 2002 tentang Komisi Pemberantasan Tindak Pidana Korupsi)sehingga kelembagaan dan fungsinya tidak bersifat independen karena masih satu lembaga sehingga fungsi checks and balances sangat diragukan;

2. Keanggotaan Dewan Pengawas KPK diangkat dan ditetapkan oleh Presiden Republik Indonesia, termasuk pemilihan Ketua Dewan Pengawas sehingga secara konseptual dan implementatif tergantung pada bagaimana kekuasaan Presiden pada periode pengangkatan (Pasal 37E Ayat 1 dan Ayat 10 Undang-UndangNomor 19 Tahun 2019 tentang Perubahan Kedua Atas Undang-Undang Nomor 30. 30 Tahun

${ }^{20}$ Agus Suntoro. Penyadapan dan Eksistensi Dewan Pengawas Komisi Pemberantasan Tindak Pidana Korupsi.Jurnal Legislasi Indonesia.Direktorat Jenderal Peraturan Perundang-undangan Kementerian Hukum dan Hak Asasi Manusia Republik Indonesia.Volume 17 Nomor 1 Maret 2020.hlm. 35.
2002 tentang Komisi Pemberantasan Tindak Pidana Korupsi).

3. Dalam pelaksanaan tugas Dewan Pengawas KPK menggantikan peran dan fungsi peradilan terutama yang berkaitan dengan keseluruhan proses penegakan hukum diantaranya meliputi penyadapan, penggeledahan, dan penyitaan padahal fungsinya bukan sebagai bagian dari penegakan hukum dalam criminal justice system.

Permasalahan lain yang muncul setelah keluarnya Undang-Undang Nomor 30 Tahun 2002 tentang Komisi Pemberantasan Tindak Pidana Korupsi menjadi Undang-Undang Nomor 19 Tahun 2019 tentang Perubahan Kedua Atas Undang-Undang Nomor 30 Tahun 2002 tentang Komisi Pemberantasan Tindak Pidana Korupsi adalah dijadikannya KPK sebagai bagian dari rumpun kekuasaan eksekutif yang melaksanakan tugas pencegahan dan pemberantasan tindak pidana korupsi, sebagaimana yang tertuang dalam Pasal 1 ayat 3 dan Pasal 3 revisi undang-undang KPK. Dalam pertimbangannya di Putusan MK Nomor 40/PUU-XV/2017, MK menyatakan bahwa KPK merupakan lembaga yang berada di ranah kekuasaan eksekutif dan melaksanakan tugas penyelidikan, penyidikan, serta penuntutan dalam perkara tindak pidana korupsi, walaupun sebenarnya hal tersebut merupakan kewenangan Kepolisian dan/atau Kejaksaan. Ditambah lagi praktek di beberapa negara, lembaga yang melaksanakan fungsi penyidikan dan penuntutan dapat dimasukkan sebagai bagian dari kekuasaan eksekutif.Bahkan menurut Putusan MK tersebut KPK dapat dijadikan objek hak 
angket ${ }^{21}$ oleh DPR mengingat fungsi KPK sebagai lembaga khusus untuk mendorong agar pemberantasan korupsi dapat berjalan secara efektif, efisien, dan optimal. ${ }^{22}$ Hal ini tentu saja menimbulkan kontroversi, ini terlihat dari beberapa hakim MK yang menyatakan dissenting opinion (pendapat berbeda) terkait apakah KPK dapat dijadikan objek hak angket oleh DPR. Hakim MK yang menyatakan bahwa KPK tidak dapat dijadikan sebagai objek hak angket karena KPK merupakan lembaga

$\begin{array}{ccc}{ }^{21} \mathrm{Hak} & \text { angket } & \text { merupakan } \\ \text { pelaksanaan } & \text { pengawasan } & \text { parlemen }\end{array}$ pemerintah atau eksekutif.Awal mulanya hak angket berkembang di Inggris, khususnya pasca Glorius Revolution (1688) yang ditandai dengan runtuhnya kekuasaan monarkhi absolut di Inggris, sehingga lahir praktek pemerintahan yang bertanggung jawab (kepada parlemen) sebagai dasar sistem pemerintahan parlementer Inggris.Model seperti ini sekarang dikenal dengan istilah mosi tidak percaya. Menurut Pasal 79 Ayat 3 Undang-Undang Nomor 17 Tahun 2014 tentang MPR, DPR, DPRD, dan DPD, hak angket DPR adalah hak untuk melakukan penyelidikan terhadap pelaksanaan suatu undang-undang dan/atau kebijakan pemerintah yang berkaitan dengan hal penting, strategis, dan berdampak luas pada kehidupan masyarakat, berbangsa, dan bernegara yang diduga bertentangan dengan peraturan perundang-undangan”. Lalu mengapa hak angket ini ditujuan kepada KPK? karena : a) adanya temuan Badan Pemeriksa Keuangan (BPK) tentang penyimpangan penyelenggaraan keuangan; b) terkait tata kelola dokumentasi dalam proses hukum penindakan dugaan korupsi, dengan adanya kasus pembocoran dokumen dalam proses hukum tersebut seperti berita acara pemeriksaan, sprindik, dan surat cekal; c) adanya dugaan perpecahan internal dan ketidakharmonisan di tubuh KPK, bahkan sikap insubkoordinasi dari kalangan internal dengan pimpinannya Komisioner KPK. Mei Susanto. Hak Angket Sebagai Fungsi Pengawasan Dewan perwakilan Rakyat.Jurnal Legislasi. Direktorat Jenderal Peraturan Perundang-undangan Kementerian Hukum dan Hak Asasi Republik Indonesia.Volume 11 Nomor 3 Desember 2018.hlm. 391 dan 398.

${ }^{22}$ Lihat dalam Putusan MK Nomor 40/PUU-XV/2017 Halaman 181. independen yang berada di luar trias politica.

Jika dianalisis lebih lanjut sebetulnya bunyi Pasal 3 Undang-Undang Nomor 30 Tahun 2002 tentang Komisi Pemberantasan Tindak Pidana Korupsi menjadi Undang-Undang Nomor 19 Tahun 2019 tentang Perubahan Kedua Atas Undang-Undang Nomor 30 Tahun 2002 tentang Komisi Pemberantasan Tindak Pidana Korupsi kontradiktif dan cenderung multitafsir, karena bagaimana mungkin KPK bisa independen dan betul-betul bebas dari pengaruh kekuasaan manapun (termasuk kekuasaan eksekutif), sementara prasyarat sebuah lembaga dapat dikatakan independen jika memiliki karakteristik di bawah ini : ${ }^{23}$

1. Dasar hukum pembentukannya menyatakan secara tegas kemandirian atau independensi dari lembaga negara independen untuk melaksanakan tugas dan fungsinya;

2. Independen, dalam artian bebas dari pengaruh, kehendak, ataupun kontrol dari cabang kekuasaan eksekutif;

3. Pemberhentian dan pengangkatan anggota komisi menggunakan mekanisme tertentu yang diatur khusus, bukan semata-mata kehendak Presiden;

4. Kepemimpinan komisi bersifat kolektif kolegial, jumlah pimpinan ganjil, dankeputusan diambil secara mayoritas suara;

5. Kepemimpinan komisi tidak dikuasai atau tidak mayoritas berasal dari partaipolitik tertentu;

6. Masa jabatan para pemimpin komisi definitif, habis secara bersamaan, dan dapat diangkat kembali untuk satu periode berikutnya;

7. Keanggotaan lembaga negara ini terkadang ditujukan untuk menjagake-

\begin{tabular}{lrr}
\hline \multicolumn{1}{c}{${ }^{23}$ Ario } & Danang & Pambudi.Tinjauan \\
Ketatanegaraan & Dewan & Pengawas \\
KPK.https://fh.unpad.ac.id/tinjauan-ketatanegaraan- \\
dewan-pengawas-kpk/ diakses & 14 & Februari 2021.
\end{tabular}


seimbangan perwakilan yang bersifat non partisan.

Contoh lembaga negara yang jika dianalisis dapat dikategorikan independen karena memenuhi beberapa karakteristik di atas adalah Komisi Pemilihan Umum (KPU), Badan Pengawas Pemilu (Bawaslu), Komisi Pengawas Persaingan Usaha (KPPU), Komisi Penyiaran Indonesia (KPI), Ombudsman Republik Indonesia (ORI), Pusat Pelaporan dan Analisis Transaksi Ke-uangan (PPATK), Komisi Yudisial (KY), Komisi Nasional Hak Asasi Manusia (Komnas HAM), Komisi Nasional Anti Kekerasan Terhadap Perempuan (Komnas Perempuan), Komisi Pemberantasan Korupsi (KPK), Komisi Perlindungan Anak (KPA), Dewan Pers, Dewan Pendidikan, Komisi Informasi, Lembaga Perlindungan Saksi dan Korban. ${ }^{24}$

Dalam teori lembaga negara kontemporer, kedudukan lembaga negara independen adalah sejajar dengan lembaga menurut teori trias politica yang terdiri dari eksekutif, legislatif, dan yudikatif.Lembaga negara independen dapat dikategorikan sebagai pilar keempat dalam pembagian kekuasaan negara. Hal senada juga dikemukan YVes Manny dan Andrew Knapp, ia menempatkan lembaga negara independen sebagai cabang kekuasaan keempat atau The Fourth Branch of Government. ${ }^{25}$ Pendapat tersebut beresonansi dengan konsep The New Separation yang dibawa oleh Brucke Ackerman yang pada intinya menganggap bahwa lembaga independen ini kedudukannya sejajar dengan lembaga eksekutif, legislatif, dan yudikatif. ${ }^{26}$

\footnotetext{
${ }^{24}$ Kelik Iswandi dan Nanik Prasetyoningsih. Kedudukan State Auxiliary Organ Dalam Sistem Ketatanegaraan di Indonesia. Jurnal Penegakan Hukum dan Keadilan.Fakultas Hukum Universitas Muhammadiyah Yogyakarta. Volume 1 Nomor 2 September 2020. hlm. 158.

${ }^{25}$ Allan Fatchan Gani Wardhana. KPK Bukan Eksekutif", https://pshk.uii.ac.id/2018/02/kpk-bukan-eksekutif/ diakses tanggal 15 Februari 2021.

${ }^{26}$ Ibid.
}

Selain itu ada beberapa argumentasi yang menguatkan kedudukan KPK sebagai lembaga negara tersendiri yang sejajar dengan trias politica, diantaranya adalah ratio legis ${ }^{27}$ yang terdapat dalam Undang-Undang Nomor 30 Tahun 2020 tentang Komisi Pemberantasan Tindak Pidana Korupsi berikut ini :28 "Bahwa sesuai dengan ketentuan Pasal 43 Undang-Undang Nomor 31 Tahun 1999 tentang Pemberantasan Tindak Pidana Korupsi sebagaimana telah diubah dengan Undang-Undang Nomor 20 Tahun 2001 tentang perubahan atas Undang-Undang Nomor 31 Tahun 1999 tentang Pemberantasan Tindak Pidana Korupsi, perlu dibentuk Komisi Pemberantasan Tindak Pidana Korupsi yang independen dengan tugas dan wewenang melakukan pemberantasan tindak pidana korupsi"

Ratio legis pembentukan Komisi Pemberantasan Korupsi a quo, menunjukkan bahwa peralihan tugas-tugas dan fungsi-fungsi lembaga eksekutif menjadi lembaga independen sesuai indikator lembaga negara independen sebagaimana yang dikemukakan oleh William F. Fox Jr. Yang berargumen bahwa suatu komisi negara adalah independen bila dinyatakan secara tegas oleh kongres dalam undang-undang komisi yang bersangkutan. ${ }^{29}$ Argumentasi Fox tersebut juga relevan dengan pendapat Lisa Schultz Bressman dan Robert B. Thompson, bahwa untuk menentukan apakah lembaga negara tersebut sebagai Independent Agencies ataukah sebagai Executive-Branch, tidak ada cara lain hanya melalui parlemen sebagai pembentuk undang-undang untuk mendesain lembaga negara pada lapis kedua (pembentukannya berdasarkan undang-unda$\mathrm{ng}) .^{30}$

${ }^{27}$ Ratio legis adalah alasan pertimbangan mengapa diperlukan ketentuan seperti itu dalam undang-undang.

${ }^{28}$ Lihat dalam Undang-Undang Nomor 30 Tahun 2002 tentang Komisi Pemberantasan Tindak Pidana Korupsi.

\footnotetext{
${ }^{29}$ Ismail Aris. Op. Cit. hlm. 102-103.

${ }^{30} \mathrm{Ibid}$.
} 
Di Amerika Serikat contoh lembaga yang menjalankan kewenangan eksekutif dan dialihkan menjadi independen agencies adalah The Commodity Futures Trading Commision (CFTC) berdasarkan Commodity Exhange Act 12. Demikian juga dengan komisi negara independen di Amerika Serikat adalah lembaga negara federal yang tidak termasuk cabang kekuasaan eksekutif, dan karenanya tidak berada di bawah kontrol Presiden. Argumentasi hukum hakim-hakim Mahkamah Konstitusi yang dissenting opinion dalam putusannya tahun 2017 juga kuat karena KPK secara teori ketatanegaraan modern adalah lembaga negara independen di luar trias politica, sehingga jelas bukan merupakan bagian dari eksekutif. Satu hakim MK lain berpandangan bahwa KPK masuk dalam ranah kekuasaan eksekutif tetapi berciri independen, karena tidak bertanggung jawab langsung kepada Presiden melainkan kepada publik dengan menyampaikan laporan secara terbuka dan kepada Presiden, Dewan Perwakilan Rakyat, serta Badan Pemeriksa Keuangan sesuai dengan ketentuan undang-undang. Hal ini dapat juga diartikan sebagai salah satu bentuk checks and balances antara KPK dengan lembaga negara lainnya.

Demikian pula dengan hasil Kajian dari Asosiasi Pengajar Hukum Tata Negara dan Hukum Administrasi Negara tahun 2017 yang dikemukakan oleh ketuanya saat itu Moh.Mahfud MD yang menyatakan bahwa, KPK tidak bisa menjadi objek hak angket karena bukan merupakan bagian dari ranah kekuaasaan eksekutif. ${ }^{31}$ Pernyataan yang dikemukakan ini bersandar pada Pasal 79 ayat 3 Undang-Undang Nomor 17 Tahun 2014 tentang MPR, DPR, DPRD, dan DPD juga penjelasannya yang menyatakan bahwa pelaksanaan suatu undang-undang dan/atau kebijakan pemerintah dapat berupa kebija-

\footnotetext{
${ }^{31}$ Asosiasi Pengajar Hukum Tata Negara Akan Sampaikan Hasil Kajian Hak Angket DPR. https://nasional.kompas.com/read/2017/06/14/11013 931/asosiasi.pengajar.hukum.tata.negara.akan.sampa ikan.hasil.kajian.hak.angket.kpk.?page=all diunduh 17 Februari 2021.
}

kan yang dilaksanakan sendiri oleh Presiden, Wakil Presiden, Menteri Negara, Panglima TNI. Kapolri, Jaksa Agung, atau pimpinan lembaga pemerintah non kementerian.

Dari beragam argumentasi tersebut penulis juga menganggap KPK adalah lembaga negara independen di luar struktur organ negara yang utama.Hal ini sejalan dengan theory the new separation of power yang tidak lagi menganggap organ negara hanya terbatas pada trias politica dan teori negara kesejahteraan yang dipraktekkan di banyak negara.Menurut teori negara kesejahteraan, untuk mencapai kesejahteraan masyarakat dalam sebuah negara maka tiga pilar kekuasaan negara yang utama (trias politica) tidaklah cukup karena kebutuhan masyarakat modern semakin kompleks. Dengan kata lain, menyesuaikan kebutuhan di abad modern, penyelenggaraan negara tidak bisa lagi bertumpu semata-mata pada kekuasaan trias politica.

Walaupun KPK dikategorikan sebagai lembaga negara independen, akan tetapi sifatnya adalah ad hoc (bukan permanen layaknya lembaga penegak hukum seperti Kepolisian dan Kejaksaan). Menurut penulis KPK dapat saja dibubarkan jika institusi Kepolisian dan Kejaksaan sudah bersih dari kasus-kasus korupsi dan layak kembali dipercaya untuk melaksanakan penegakan hukum $^{32}$ dalam rangka pemberantasan tindak pidana korupsi di Indonesia.Selama hal ini belum terwujud, maka keberadaan KPK di Indonesia tetap dibutuhkan sampai jangka waktu yang belum dapat ditentukan.Jadi, yang menjadi persoalan paling penting saat ini sesungguhnya adalah pembenahan dan

${ }^{32}$ Menurut Lawrence M. Friedman ada tiga faktor yang mempengaruhi penegakan hukum, yaitu : 1. substansi hukum (substance law), adalah perturan perundang-undangan yang dibuat secara baik (memenuhi unsur yuridis, filosofis, dan sosiologis); 2. struktur hukum (structure law), yang terdiri dari apararat penegak hukum yang berintegritas dan profesional serta fasilitas yang mendukung penegakan hukum; 3. budaya hukum (legal culture), adalah ketaatan masyarakat terhadap aturan hukum yang dibuat oleh pembuat peraturan perundang-undangan. 
perbaikan lembaga penegak hukum, yaitu Kepolisian dan Kejaksaan.

\section{Kesimpulan}

Kedudukan KPK dalam sistem ketatanegaraan Indonesia memang menjadi perdebatan. Ada yang berargumen KPK merupakan bagian dari kekuasaan eksekutif karena melaksanakan fungsi penyidikan, penyelidikan, dan penuntutan sebagaimana dilakukan oleh lembaga Kejaksaan dan Kepolisian yang termasuk eksekutif. Akan tetapi ada argumentasi yang tidak kalah kuat yang menyatakan bahwa KPK merupakan lembaga independen yang bebas dari pengaruh kekuasaan eksekutif, legislatif,dan yudikatif (trias politica). Hal tersebut didasarkan karena KPK mempunyai wewenang untuk melaksanakan penegakan hu- kum dalam rangka pemberantasan tindak pidana korupsi, dimana kejahatan ini dapat dikategorikan sebagai kejahatan luar biasa. Untuk itulah KPK harus independen dalam melaksanakan wewenangnya. Sebagai lembaga negara independen yang kedudukannya tidak sekuat lembaga negara utama menurut teori trias politica, tentu saja KPK bisa dibubarkan jika lembaga yang selama ini sebetulnya mempunyai wewenang kuat dalam rangka pemberantasan tindak pidana korupsi (Kepolisian dan Kejaksaan) mampu berbenah diri. Selama belum mampu berbenah maka wewenang tersebut bisa dilaksanakan oleh KPK yang keberadaannya sampai saat ini masih tetap diperlukan dalam rangka pemberantasan tindak pidana korupsi di Indonesia.

\section{DAFTAR PUSTAKA}

\section{BUKU-BUKU}

Hamdan Zolva, dkk. Bunga Rampai Pemikiran Penataan Lembaga Non Struktural. Jakarta: Deputi Menteri Sekretaris Negara Bidang Hubungan dan Kelembagaan. 2010.

I D.G. Palguna.Welfare State vs Globalisasi: Gagasan Negara Kesejahteraan di Indonesia. Depok: PT RajaGrafindo Persada. 2019.

Moh. Mahfud MD. Perdebatan Hukum Tata Negara Pasca Amandemen Konstitusi. Jakarta: PT RajaGrafindo Persada. 2013.

Saldi Isra. Lembaga Negara: Konsep Sejarah Wewenang dan Dinamika Konstitusional. Depok: PT RajaGrafindo Persada. 2020.

\section{PERATURAN}

Undang-Undang Nomor 30 Tahun 2002 tentang Komisi Pemberantasan Tindak Pidana Korupsi.

Undang-Undang Nomor 19 Tahun 2019 tentang Perubahan Kedua Atas Undang-Undang Nomor 30 Tahun 2002 tentang Komisi Pemberantasan Tindak Pidana Korupsi.

Putusan MK Nomor 36/PUU-XV/2017.

Putusan MK Nomor 37/PUU-XV/2017.

Putusan MK Nomor 40/PUU-XV/2017.

\section{JURNAL-JURNAL}

Agus Suntoro. Penyadapan dan Eksistensi Dewan Pengawas Komisi Pemberantasan Tindak Pidana Korupsi.Jurnal Legislasi Indonesia.Direktorat Jenderal Peraturan Perundang-undangan Kementerian Hukum dan Hak Asasi Manusia Republik Indonesia.Volume 17 Nomor 1 Maret 2020.

Ismail Aris. Kedudukan KPK Dalam Sistem Ketatanegaraan Dalam Perspektif Teori The New Separation of Power (Kritik Atas Putusan Mahkamah Konstitusi No, 36/PUU-XV/2017 dan No. 40/PUU-XV/2017. Jurnal Jurisprudentie. Fakultas 
Syariah dan Hukum Universitas Islam Negeri Alauddin Makassar.Volume 5 Nomor 1 Juni 2018.

Kelik Iswandi dan Nanik Prasetyoningsih. Kedudukan State Auxiliary Organ Dalam Sistem Ketatanegaraan di Indonesia. Jurnal Penegakan Hukum dan Keadilan.Fakultas Hukum Universitas Muhammadiyah Yogyakarta, Volume 1 Nomor 2 September 2020 .

Mei Susanto. Hak Angket Sebagai Fungsi Pengawasan Dewan perwakilan Rakyat.Jurnal Legislasi, Jurnal Legislasi Indonesia, Direktorat Jenderal Peraturan Perundang-undangan Kementerian Hukum dan Hak Asasi Manusia Republik Indonesia. Volume 11 Nomor 3 Desember 2018.

\section{INTERNET}

Allan Fatchan Gani Wardhana. KPK Bukan Eksekutif. https://pshk.uii.ac.id/2018/02/kpk-bukan-eksekutif/ diunduh 15 Februari 2021.

Ario Danang Pambudi.Tinjauan Ketatanegaraan Dewan Pengawas

$K P K$.https://fh.unpad.ac.id/tinjauan-ketatanegaraan-dewan-pengawas-kpk/ diunduh 14 Februari 2021.

Mudzakkir, dkk.Laporan Akhir Tim Kompendium Hukum Badan Pembinaan Hukum Nasional Kementerian Hukum dan Hak Asasi Manusia Republik Indonesia Tentang Lembaga Pemberantasan Korupsi Tahun

2011.https://bphn.go.id/data/documents/kpd-2011-7.pdf diunduh 16 Februari 2021.

Asosiasi Pengajar Hukum Tata Negara Akan Sampaikan Hasil Kajian Hak Angket DPR”. https://nasional.kompas.com/read/2017/06/14/11013931/asosiasi.pengajar.huku m.tata.negara.akan.sampaikan.hasil.kajian.hak.angket.kpk.?page=all diunduh 17 Februari 2021.

Di Bawah Kendali Politik Kekuasaan. https://koran.tempo.co/read/editorial/459402/di-bawah-kendali-politik-kekuasaan diunduh 14 Februari 2020.

Sekilas Komisi Pemberantasan Korupsi. https://www.kpk.go.id/id/tentang-kpk/sekilas-komisi-pemberantasan-korupsi diunduh 12 Februari 2021. 